\title{
Tiga Dimensi Warna Demokrasi Indoensia: Kajian Semiotik (Roland Barthes
}

\author{
Kholid $^{1}$ \\ ${ }^{1}$ Universitas Udayana
}

*Kholid, Universitas Udayana; Email:

Kholidlid45@gmail.com

\begin{abstract}
Tujuan penelitian ini adalah untuk mendeskripsikan suatu fenomena etika dalam berkomunikasi dalam ranah sosial politik di media sosial. Adapun yang dikaji dalam penelitian ini adalah dari perspektif bahasa teks wacana di media. Dalam penelitian ini, adapun pendekatan yang digunakan adalah pendekatan kualitatif metode pengumpulan data dengan metode observasi dan dokumentasi. Metode analisis data, sebagai langkah awal peneliti mengklasifikasi data menjadi beberapa kategori kemudian menganalisis satu persatu dari data yang ditemukan, kemudian peneliti memberikana interpretasi dari semua data tersebut dengan cara mendeskripsikan terlebih dahulu, kemudian diberikan interpretasi sesuai konteks. Kajian semiotik merupakan teori atau pijakan pada penelitian ini dengan tujuan untuk menganalisis fenomena kondisi tiga deminsi demokrasi dalam perspektif bahasa politik.
\end{abstract}

Keywords: Semiotik, Warna, Demokrasi, Politik

\section{Pendahuluan}

Sudah kita ketahui bersama bahwa pada 2018-2019 merupakan tahun kontestasi pesta demokrasi, Pilkada sudah selesai diselenggarakan pada beberapa bulan yang lalu. Pada saat ini proses sedang berlangsung tahapan-tahapan dari Pilpres dan Pileg baik tingkat kabupaten, provinsi, dan tingkat pusat. Oleh karena itu, kita harus bersikap bijak dalam menjalani segala proses baik pilpres dan pileg, sebagaimana yang sudah disahkan baik secara administratif maupun kompetensi. Selain itu para pendukung dari semua calon baik dalam Pilpres maupun pilleg harus bersikap bijak dalam menjalani pesta demokrasi pada masa dewasa saat ini, supaya terwujud perkembangan sistem demokrasi lebih berkembang dan lebih dewasa.

Sistem demokrasi yang menentukan arah atau posisi Negara atau bangsa yang kita cintai ini, oleh karena itu jika suatu sistem demokrasi tidak ada perubahan selama ini lebih-lebih dalam menjalani semua proses dari kontestasi pesta demokrasi, baik para pelaku, dan pendukung yang tidak memiliki kesadaran ingin berubah, dalam menjalani semua proses tersebut dengan cara bersikap yang bijak, dalam menjalani semua proses kontestasi pesta demokrasi saat ini. Maka posisi dari sebuah Negara atau bangsa tidak memiliki arah yang pasti, akan mau dibawa kemana sebuah kapal ini untuk berlabuh oleh "Nahkoda" atau posisi Negara atau bangsa ini akan menjadi terapung di tengah lautan selama-lamanya.

Terkait dengan semua hal itu, tahapan demokrasi yang paling "ekstrem" atau menghalalkan segala cara adalah tahapan "Kampanye" yang menjadi fenomena selama ini, sebenarnya kalau kita melihat dari segi makna kata dalam kamus bahasa indonesia "kampanye" adalah kegiatan yang dilakasanakn oleh organisasi politik atau calon yang bersaing merebutkan kedudukan diparlemen atau untuk mendapatkan dukungan masa pemilih. Lebih sederhananya kata "kampanye" secara "semantik" merupakan tahapan proses sosialisasi visi dan misi yang diberikan kesempatan kepada semua calon baik dalam Pileg maupun Pilpres oleh KPU dan memiliki aturan tertentu, hal ini sudah diatur dalam Undang-undang 
pemilu. Dengan demikian dalam proses sosialisasi visi dan misi atau "kampanye", dari kata "kampanye" itu sendiri muncul tiga dimensi warna dalam pesta demokrasi di Indonesia saat ini, diantara ketiga warna tersebut termasuk kategori proses dalam pesta demokrasi.

Berdasarkan uraian di atas tentang fenomena kondisi demokrasi Indonesia saat ini. Menurut peneliti menarik untuk dikaji dalam perspektif pemakaian bahasa yang di kategorikan sebagai tiga dimensi warna demokrasi Indonesia saat ini, dengan membedah permasalah tersebut menggunakan kajian semiotik yang diperkasai oleh Barthes. Perkembangan ilmu memang tetap bersipat dinamis sesuai dengan perkembangan zama, begitu pula dalam kajian perspektif ilmu linguistik. Kajian Semiotik dilihat dari segi history merupakan kajian ilmu tanda yang awalnya dikembangkan oleh De Saussure kemudian dikembangkan oleh Barthes dengan melihat pemaknaan tanda secara dinamis.

De Saussure (dalam Sabur, 2006) dikenal dengan pengembangan teori perspektif ilmu tanda yang identik dengan dua konsep bahwa bahasa itu adalah suatu sistem tanda, dan setiap sistem tanda itu tersusun dari dua bagaian, yakni Signifier (penanda) dan Signified (petanda). Kemudian hal tersebut dikembangkan oleh Bartnes yang berpendapat bahwa bahasa adalah sistem tanda yang terdiri dari suatu bentuk penanda (signifier) dengan sebuah idea tau petanda (signfied). Dengan kata lain, petanda adalah 'bunyi yang bermakna' atau 'coretan yang bermakna'. Jadi tentu sudah jelas penand adalah aspek material yang bersifat kongkrit dari bahasa itu sendiri: apa yang dikatakan atau didengar dan apa yang ditulis atau dibaca. Petanda adalah gambaran mental yang bersifat abstrak yang berupa konsep atau pikiran. Jadi petanda adalah aspek mental dari bahasa (Bertnes, 2001: 180). Selain itu Barthes (1977) merumuskan tanda sebagai sistem yang terdiri atas expression (E) yang berkaitan (relation -R-) dengan content (C). sistem tanda menurut Barthes (1977) mengembangkan teori semiotik ke dalam dua sistem pertandaan sebagai berikut:

\begin{tabular}{|l|l|}
\hline Signifier $\quad$ Signified & \\
\hline Denotative sign & \\
\hline Connotative signifier & $\begin{array}{l}\text { Conotatif } \\
\text { signifier }\end{array}$ \\
\hline Connotative sign & \\
\hline
\end{tabular}

Gambar 1: Skema teori Semiotik Barthes (1915-1980)
Berdasarkan pendapat Berthes di atas tentu sudah jelas bahwa makna tanda berbsifat dinamis sesuai dengan teks dan konteks sebagai acuan, sehingga memiliki makna yang berbeda dengan makna yang pertama dengan makna kedua. Teori Berthes sudah dikenal dengan teori makan dua sisi yakni makna denotasi dan makna konotasi dalam mengungkapkan suatu fenomena tanda dalam suatu pemakaian bahasa verba maupun non verba.

\section{Metode}

Penelitian ini lebih bersifat deskriptif kualitatif, hal ini disesuaikan dengan data yang akan dikaji. Data dalam penelitian ini, membahasa tentang simbol-simbol pemakaian bahasa dalam konteks politik. Sebagai langlah awal peneliti mengamati beberapa simbol-simbol pemakian bahasa dalam konteks politik terssebut, setelah pengamatan dilakukan langkah berikutnya peneliti mengklasifikasi data. Data yang sudah diklasifikasi, maka sebagai langkah selanjutnya peneliti memberikan sebuah analisis dan mendeskripsikan beberapa simbol-simbol pemakaian bahasa tersebut dengan cara menginterpretasikan semua bagian dari simbol-simbol pemakaian bahasa dalam konteks politik tersebut.

\section{Hasil dan Pembahasan}

Berdasarkan hasil temuan data atau secara ontologi dan pengamatan dari pihak peneliti bahwa selama ini, warna demokrasi Indonesia saat ini memiliki tiga warna sesuai dengan data empiris. Untuk lebih jelasnya pada kesempatan ini peneliti mendeskripsikan warna demokrasi tersebut dalam perspektif lingusitk.

Pertama, warna "putih" memiliki makna denotasi (denotative maening) sebagai tanda sebuah warna yang bersih dari noda hal ini makna secara leksikal memiliki makna warna dasar yang serupa dengan warna kapas atau kain kapan. Warna "putih" memiliki makna konotasi (conotative maening) sebagai tanda yang melambangkan kebersihan atau kesucian dari tindakan yang tidak terpuji. Kemudian pada waran ini dikenal dengan istilah dalam bahasa politik "kampanye positif" (Positive Campaign) yang memiliki arti "kampanye" atau tindakan dengan cara menyampaikan tentang kelebihan-kelebihan calon lain, atau kelebihan pada visi dan misi, program dan kerja-kerja yang telah dilakukan. Secara sederhana menyampaikan kelebihan lawan politik 
baik dari segi visi dan misi dengan cara tidak mencari keburukan atau kesalahannya. Seharusnya hal ini harus dilakukan oleh semua calon anggota parlemen dan presiden lebih-lebih para pendukung, akan tetapi faktanya hal ini jauh dari harapan. Kita harus optimistik dalam segala hal, baik dalam kehidupan bermsyarakat maupun bernegara, oleh karena itu marilah kita bangkit untuk menuju perubahan dari jeritan yang tidak baik di masa yang silam dengan cara selalu menebarkan kebaikan kedamaian dari berbagai aspek bukan aspek politik saja.

Kedua, warna "abu $a b u$ " kalau dilihat dari segi leksikal dan dilihat dari makna tanda denotasi (denotative maening) merupakan warna antara hitam dan putih atau hal tersebut serupa dengan abu kayu bakar. Akan tetapi hal ini memiliki makna sangat berbeda kalau dilihat dari makna tanda konotasi (conotative maening) merupakan suatu tindakan yang tidak baik, kata tersebut dalam bahasa politik disebut "kampanye negative" (negative campaign), yang memiliki makna "kempanye" atau melakukan tindakan dengan cara menyampaikan tentang kekurangan-kekurangan yang dimiliki oleh calon lain/viral, kekurangan yang disampaikan bersifat fakta dan didukung oleh data yang kuat dan terpercaya. Hal ini secara sederhana jangan kita mencari kesalahan calon lain meskipun kesalahan orang itu benar ada, hal ini dilihat dalam konteks politik. Memang hal demikian manurut konsep agama Islam kata "Negative Campaign"dalam bahasa Arab dikatakan sebagai kata "Ghibah" atau menggunjing orang lain dalam arti membicarakan kesalahan orang lain meskipun benar. Semua hal ini harus kita hindari untuk mencapai "baldatun thaibatun warrabunggafur" karena Negara kita ini memiliki ideologi tidak menyimpang dari nilai agama yakni ideologi pancasila di mana pada sila pertama sudah jelas "Ketuhanan Yang Maha Esa" artinya secara hukum agama dan hukum Negara tindakan "kampanye negative" (negative campaign) merupakan tindakan yang dilarang. Oleh karen itu marilah kita hindari warna abu-abu dalam kehidupan dalam bermasyarakat maupun bernegara.

Ketiga, warna "hitam" memiliki makna sebuah warna dasar yang serupa dengan warna arang hal tersebut termasuk dalam kategori makna tanda denotasi (denotative maening). Kemudian warna hitam kalau dilihat dari sisi makna tanda konotasi (conotative maening) merupakan simbol atau melambangkan hal yang identik dengan suatu keburukan atau hal yang tidak baik, hal ini kalau dikaitkan dalam istilah bahasa politik sebagai kata "kampanye hitam" (bleck campaign) artinya bahwa kampanye dengan cara membuat berita bohong (hoax) bertujuan untuk menyerang calon lain, fitnah yang disampaikan tidak didukung oleh data dan jauh dari nilai kebenaran, hal ini sama sekali tidak dibenarkan untuk dilakukan. Akan tetapi hal ini seiring dengan perkembangan teknologi pada saat ini tidak bisa dibendung dengan hal-hal yang demikian, lebih-lebih pada masa pesta demokrasi saat sekarang sudah menjadi kultur dalam perkembangan politik di Indonesia saat ini. Dari segi hukum Islam memang hal yang demikian tidak dibenarkan sebagaimana firman Allah SWT dalam Surah An-Nur

"Artinya. Dan seandainya bukan karena karunia Allah dan rahmat-Nya kepadamu di dunia dan akhirat, niscaya kamu akan ditimpa azab yang besar, disebabkan oleh pembicaraanmu tentang (berita bohong) itu, ingatlah ketika kamu menerima (berita bohong) itu dari mulut ke mulut dan kamu katakana dari mulutmu itu apa yang tidak kamu ketahui sedikitpun, dan kamu menganggapnya remeh, padahal dalam pandangan Allah itu suatu perkara yang besar. (QS. An-Nur 24: 14-15).

Berdasarkan ayat di atas, memang sudah jelas Allah SWT sangat mengecam bagi pelaku baik yang memproduksi atau menyeabar berita bohong (hoax). Dalam konsep ajaran Islam sudah diatur tata cara berkomunikasi yang baik, hal ini sudah dijelaskan dalam QS. Al-Ahzab 33: 70-71

"Artinya. Hai orang-orang yang beriman, bertaq-walah kamu kepada Allah dan sampai-kanlah perkataan yang benar. Allah akan memperbaiki bagi amalan-amalanmu dan mengampuni bagi dosa-dosamu. Dan barang siapa yang mematuhi Allah dan Rasul-Nya maka ia akan memperoleh sukses yang besar. (QS. Al-Ahzab 33: 70-71)". Selain dari hukum Islam tentu sudah kita ketahui bersama bahwa Negara kita adalah Negara hukum untuk itu segala hal sudah diatur dalam UUD 1945, seperti kaitannya dengan hal berita bohong (hoax) sendiri sudah tercantum dalam UU ITE Undang-Undang Republik Indonesia Nomor 11 tahun 2008 tentang informasi dan transaksi Elektronik Pasal 28 ayat 1 dijelaskan bahwa setiap orang dengan sengaja dan tanpa hak menyebarkan berita bohong dan menyesatkan yang 
mengakibatkan kerugian, dipidana dengan penjara paling lama 6 (enam) tahun dan/atau denda paling banyak Rp1.000.000.000 (satu miliyar rupiah).

\section{Kesimpulan}

Berdasarkan hasil temuan data empiris atau ontologism dan analisis berdasarkan beberapa acuan atau efistimologis, bahwa menggambarkan tiga waran demokrasi Indonesia saat ini. Diantara tiga warna tersebut dilihat dari segi ontologinya, efistimologi dan aksilogi dari perspektif bahasa dapat disimpulkan bahwa.

1. Warna "putih" dari segi semantik memiliki makna sesuatu yang menggambarkan keadaan sesuatu yang suci dan dikenal dalam simbol kesucian yang memiliki makna tidak ada noda apapun atau suci dari noda dan dosa. Dengan demikian terkait dengan konteks demokrasi di sini bahwa warna putih diartikan sebagai langkah yang baik dan ucapan yang baikpula tidak mencari-cari kesalahan orang lain. Dalam artian berkata yang jurdil dan tidak membohongi orang lain dalam kontestasi apapun baik politik dan lain-lain.

2. Warna "abu-abu" kalau ditinjau dari segi lingustik bahwa abu-abu melambangkan suatu hal keadaan yang belum jelas kepastian dan kejelasan dalam segala hal baik dari segi perkataan maupun perbuatan. Akan tetapi abuabu yang dimaksud di sini, memiliki makna selalu menceritakan kejelekan orang lain dan membandikan dengan diri sendiri dalam konteks politik. Semua hal ini, yang tidak bisa dipungkiri pada era demokrasi saat ini.

3. Warna "hitam" kata hitam merupakan lawan dari kata putih. Dari segi semantik kata hitam melambangkan sesuatu keadaan yang terburuk atau tidak memiliki padangan dalam hidup yang dibekali oleh sinar cahaya. Dalam koteks di sini warna hitam diartikan sebagai sesuatu tindakan seseorang dalam mencapai tujuan dengan cara tidak memikirkan baik buruk atau dampak yang akan diakibatkan oleh perkataan maupun perbuatan dalam berkomunikasi politik. Sudah jelas pada konteks ini, tentu sudah marak terjadi dan tidak bisa dipungkiri oleh siapapun, akan tetapi harus kita optimistik dalam hal perubahan menuju khasanah baik dari segi bahasa dan perbuatan.

\section{Saran}

Kajian pemakaian bahasa dalam konteks politik sangat menarik untuk dikaji dari sisi perspektif ilmu bahasa. Pada penelitian ini, menggunakan teori semiotik versi Barthes yang sangat mudah, praktis dan mendukung dalam pengungkap suatu permasalahan sosial dalam hal ini pemakaian bahasa yang fokus pada sisi simbol-simbol pemakaian bahasa, hal ini dilihat dari persepektif ilmu bahasa. Berdasarkan semua hal ini, ditujukan kepada peneliti selanjutnya hendaknya menerapkan teori ini disesuiakan dengan permasalahan dengan melihat dari perspektif kajian bahasa baik pemakaian bahasa dari konteks apapun sehingga mengalami perkembangan yang dinamis baik secara praktis maupun akademis.

\section{Daftar Pustaka}

Barthes, Roland. 1977. Image. Music. Teks. Londen : Fontana Press

Bartnes, K, 2001. Filsafat Barat Kontemporer Perancis, Gremedia Pustaka Utama, Jakarta

Kalean, 2002, Filsafat Bahasa, Paradigm, Yogyakarta

Leahy, Louis, 1985, Manusia Sebuah Mesteri Sintesa Filosofis Mahluk Paradoks, Gramedia, Jakarta

Maksum, 2014, Pengantar Filsafat: Dari Masa Klasik Hingga Postmodernisme, Ar-Ruzz Media, Yogyakarta

Sobur, Alex, 2006. Semiotika Komunikasi. Bandung: Remaja Rosdakarya

Shihab, M. Quraish. 2002. Tafsir Al-Misbah Pesan, Kesan dan Keserasian Al-Quran. Vol. 9. Jakarta: Lentera Hati. 